\title{
Paradoxes of a Cold War Sufi woman: Sâmiha Ayverdi between Islam, nationalism, and modernity
}

\author{
ilker Aytürk \\ Laurent Mignon
}

\begin{abstract}
Widely recognized by nationalists, Islamists and conservatives as the heroine of the Turkish Right in the twentieth century, Sâmiha Ayverdi influenced the renaissance of right-wing politics in Turkey as an important leader of the Rifaî order, a prolific author, an unyielding anti-communist, and finally as an institution-builder for right-wing causes. This article focuses on the apparent paradoxes in Ayverdi's long career, such as her modernist interpretation of Islam, her relationship with her sufi master, preference for memoirs, and her unabashed elitism. Such characteristics defy clichés associated with the stereotypical conservative/nationalist/Islamist intellectual in Cold War Turkey. Our in-depth study of Ayverdi's works thus reveals the complexity of right-wing identities, and the fact that our protagonist is an outspoken woman intellectual also adds an important twist to the story.
\end{abstract}

Keywords: Ayverdi, Sufism, Muslim women, Turkish nationalism, Kemalism, Turkish literature, narratives of the self, minorities-Turkey.

In 1937, the thirty-two-year-old Sâmiha Ayverdi completed her first novel, $A$ şk $B u$ Imiş (So This Is Love). Already a passionate disciple of Kenan Rifaî, ${ }^{1}$ young Sâmiha laid the manuscript of her first book in

İlker Aytürk, Political Science and Public Administration, Bilkent University, Ankara, Turkey, ayturk@bilkent.edu.tr.

Laurent Mignon, St Antony's College, University of Oxford, Oxford, United Kingdom, laurent.mignon@ orinst.ox.ac.uk.

Authors' Note: We presented earlier versions of this article before engaging audiences at the Universities of Chicago, Oxford, Stanford and Tel Aviv. Particularly, we would like to thank Ayşe Saktanber, Ali Yaycıoğlu, and Refet Gürkaynak for insightful comments and suggestions. All remaining errors are ours.

1 There is as yet no scholarly biography of Kenan Rifaî [Büyükaksoy] (1867-1950), but collections of

New Perspectives on Turkey, no. 49 (2013): 57-89. 
the hands of the famed sheikh and told him: "My master, here is your newborn son." With this barely disguised allusion to an-intellectualinsemination, which itself was an extraordinary instance of challenging what has traditionally been considered Islamically-appropriate interaction between a man and a woman, ${ }^{2}$ she read the manuscript out to the old man and published it only after receiving his blessing. This was a ritual that she would repeat over and over until Rifaî passed away in 1950. On one occasion, her master objected to the genre of her writing; he said he did not approve of plays. Ayverdi's response was to tear that manuscript into pieces and discard the remains immediately. ${ }^{3}$ Such was Ayverdi's fidelity to her sheikh that she dedicated her entire life to honoring, and sometimes defending, the memory of Rifaî after his passing.

Sâmiha Ayverdi (1905-1993) was a nonconformist intellectual and celebrity in conservative, nationalist, and Islamist circles of 20th century Turkey. Born into an established family and being a high-ranking member of the Rifaî order ${ }^{4}$ in Turkey, Ayverdi spread her influence over a circle of like-minded intellectuals, writers, and artists through a number of family-sponsored societies and organizations. She was also the author of some forty works, ranging from Islamic propagandist pamphlets and historical novels to highly autobiographical collections of essays on Ottoman-Turkish history. Undeservedly understudied in English-speaking academia, Ayverdi had always been a revered, if rather controversial, figure of the Turkish Right, but she rose to even greater prominence posthumously during the 2000s. In 2004, the Turkish Ministry of National Education included her most widely read novel, İbrabim Efendi Kona ğı (The Mansion of İbrahim Efendi) in the official canon of 100 books to be read by all middle and high school students. ${ }^{5}$ To mark the one-hundredth anniversary of Ayverdi's birth, a prestigious high school

conversations with him or anecdotes have been published by his followers; see Sâmiha Ayverdi, Safiye Erol, Nezihe Araz and Sofi Huri, Ken'an Rifaî ve Yirminci Asrın Işığında Müslümanlık, $4^{\text {th }}$ ed. (İstanbul: Kubbealtı, 2003); Cemalnur Sargut, Kenan Rifaî Ile Aşka Yolculuk (İstanbul: Sufi Kitap Yayınları, 2011).

2 Historical accounts depicting the relationship between a male sheikh and a woman disciple are very rare. One other example is the dream-book of an early 17th century woman, Asiye Hatun of Skopje, who recorded her dreams and sent them to her sheikh for interpretation and guidance. Ironically, her dreams centered on the sheikh with unmistakable sexual overtones; see, Cemal Kafadar, "Mütereddit Bir Mutasavvıf: Üsküplü Asiye Hatun'un Rüya Defteri, 1641-1643," Topkapı Sarayı Yıllığı, 5 (1992), 168222.

3 Özcan Ergiydiren, Hayâli Cihan Değer: Sâmiha Ayverdi ile Hâtıralar (İstanbul: Kubbealtı, 2009), 370.

4 Rifais are followers of the $12^{\text {th }}$ century mystic Ahmad ar-Rifai. From its original base in Lower Iraq, Rifaiyya spread into Anatolia in the $15^{\text {th }}$ century and from there to the Balkans, where it still maintains a presence in Albania, Bosnia and Kosovo. See, C. E. Bosworth, "Rifa'iyya," Encyclopedia of Islam, $2^{\text {nd }}$ ed. (2010).

5 "100 Temel Eser," http://www.meb.gov.tr/duyurular/duyurular/10otemeleser/10otemeleser.htm, T.C. Millî Eğitim Bakanlığı, August 22, 2004, accessed June 9, 2012. 
in İstanbul was renamed after her in 2005, and the Turkish public television channel, TRT, funded and aired a documentary on Ayverdi's life and the mystical message of her works. ${ }^{6}$

A micro-level, in-depth study of an individual only makes a farreaching contribution beyond the narrow confines of the immediate historical context if that figure stood at the interface of a number of debates of interest to scholars from a wide range of disciplines. This is exactly what we found in Sâmiha Ayverdi's case, and, in this article, we aim to approach and problematize several strands of scholarship, including those on Islam and gender, Islamism and conservatism, narratives of the self by Muslim women, and Muslim anti-Semitism and anti-Christian polemics. This early, and probably first, case of a Turkish Islamicleaning activist woman and her circle went surprisingly unnoticed in the growing body of academic literature, which invariably describes Islamist women's visibility and activism as a post- 1980 phenomenon. ${ }^{7}$ In a country where female activism was historically associated with the westernized and westernizing Kemalist women, ${ }^{8}$ Ayverdi's intellectual position

6 The documentary is available on www.youtube.com in two parts.

7 Binnaz Toprak, "Religion and Turkish Women," in Nermin Abadan-Unat, Deniz Kandiyoti and Mübeccel B. Kıray, eds., Women in Turkish Society (Leiden: Brill, 1981), 281-92; Nükhet Sirman, "Feminism in Turkey: A Short History," New Perspectives on Turkey 3 (1989), 1-34; Feride Acar, "Women and Islam in Turkey," in Women in Modern Turkish Society, 46-65; Yeşim Arat, "Feminism and Islam: Consideration on the Journal Kadın ve Aile," in Women in Modern Turkish Society, 66-78; Nilüfer Göle, The Forbidden Modern: Civilization and Veiling (Ann Arbor: University of Michigan Press, 1997). It was Ayşe Saktanber who first turned the spotlight on this academic problem and discussed the root causes and context of neglect in her Living Islam: Women, Religion and the Politicization of Culture in Turkey (London and New York: I.B. Tauris, 2002), 44-8.

8 Until the 1980s, the dominant paradigm in the study of Turkish women was one of euphoric celebration of emancipation in the early republic. Turkish women were indeed granted legal and political equality in a path-breaking series of reforms during the 1920 s and 1930s, leading all observers to assume that those women who still maintained a traditional, Islamic way of life were but historical anomalies, destined to disappear with the progress of modernization. For this pre-1980 literature, see, A. Afet Inan, The Emancipation of the Turkish Women (Amsterdam: UNESCO, 1962); Afet Inan, Atatürk ve Türk Kadın Haklarının Kazanılması (İstanbul: Milli Eğitim Bakanlığı, 1968); Afet İnan, Tarih Boyunca Türk Kadınının Hak ve Görevleri (İstanbul: Milli Eğitim Bakanlığı,1975); Perihan Onay, Türkiye'nin Sosyal Kalkınmasında Kadının Rolü (Ankara: İ̧̧ Bankası Yayınları, n.d.); Tezer Taşkıran, Cumhurivetin 50. Yılında Türk Kadın Hakları (Ankara: Başbakanlık, 1973); Necla Arat, Kadın Sorunu (İstanbul: İstanbul Üniversitesi Edebiyat Fakültesi, 1980); Emel Doğramacı, Atatürk and the Turkish Women Today (Ankara: Atatürk Araştırma Merkezi, 1991). This was followed by a period of disillusionment with the rhetoric of emancipation and some scholars started to underline the fact that Kemalist reforms were mainly an urban, bourgeois phenomenon that left the rural majority of women untouched. See, Nermin Abadan-Unat, "Social Change and Turkish Women," in Women in Turkish Society, 5-31; Abadan-Unat, Women in the Developing World: Evidence from Turkey (Denver: University of Denver, 1986). Finally, in the post-1983 atmosphere, the Kemalist period received rather unfavorable attention, being cited as an example of state feminism which precluded the true liberation of women. Some important examples of this approach are, Deniz Kandiyoti, "Emancipated but Unliberated? Reflections on the Turkish Case," Feminist Studies 13 (1987), 317-38; Şirin Tekeli, ed. Women in Modern Turkish Society (London: Zed Books, 1995); Göle, The Forbidden Modern; Yaprak Zihnioğlu, Kadınsız Inkılap (İstanbul: Metis, 2003). 
is perplexing. Her life and works occupy the intersection of tradition and renewal, conservatism and the emancipation of women, Ottoman elitism and Turkish nationalism, mysticism and bourgeois life, fiction and autobiography.

This article aims to explore apparent paradoxes in Ayverdi's self-portraiture. How could a woman impose herself as an authority on a traditionally male-dominated, conservative Muslim audience and play a leading role in a Muslim mystical brotherhood, while she was a living example of a westernized and unveiled Turkish woman? Why are most of her works based on autobiographical material, exposing her daily life in her household, while Islam orders a strict separation of the private and the public spheres for women? How could Ayverdi claim to speak from inside Turkish conservatism, with its populist and egalitarian challenges to the elitism of the Kemalist establishment, while constructing an elitism of her own? Although she belongs to the Sufi tradition and celebrates the Ottoman imperial model, why did Ayverdi choose to ignore Sufi teachings and the multicultural fabric of the Ottoman society, and advocate anti-Semitic, anti-Armenian and, generally speaking, anti-Western views?

We need to clarify at this point that, while we want to highlight Ayverdi's peculiarities, we do not, in any way, wish to perpetuate Orientalist myths about docile Muslim women languishing in the harem. For centuries Ottoman women had been active in the Sufi field as patrons and disciples, and certainly more so during the later years of the empire. During the republican period too, religious orders (tarikat) may have counted thousands of women among their members. Furthermore, contours of Ayverdi's life fit into the framework of Middle Eastern middle classes: ${ }^{9}$ her story of "being modern" and preserving tradition simultaneously was and is being replicated by countless other middle and uppermiddle class women in the Middle East. ${ }^{10}$ That said, what sets Ayverdi apart from many other Muslim women of her time was that she exercised spiritual and religious authority over a mixed group of men and women disciples for nearly half a century.

9 Keith Watenpaugh, "Being Middle Class and Being Arab: Sectarian Dilemmas and Middle-Class Modernity in the Arab Middle East, 1908-1936," in A. Ricardo Lopez and Barbara Weinstein, eds., The Making of the Middle Class: Toward a Transnational History (Durham: Duke University Press, 2012); Watenpaugh, Being Modern in the Middle East: Revolution, Nationalism, Colonialism, and the Arab Middle Class (Princeton: Princeton University Press, 2006).

10 Beth Baron, Egypt as a Woman: Nationalism, Gender, and Politics (Berkeley, Los Angeles and London: University of California Press, 2005); Firoozeh Kashani-Sabet, "Patriotic Womanhood: The Culture of Feminism in Modern Iran, 1900-1941," British Journal of Middle Eastern Studies 32 (2005), 29-46; Monica M. Ringer, "Rethinking Religion: Progress and Morality in the Early Twentieth-Century Iranian Women's Press," Comparative Studies of South Asia, Africa and the Middle East 24 (2004), 47-54. 
The peculiarities of Ayverdi and her circle challenge one of the most salient truisms of modern Turkish intellectual history. As Nazım İrem has argued, "the dominant trend in the historiography of the Kemalist revolution [...] characterized the politics of the era as a zero-sum game between secular-modernist Kemalists [...] and religiously oriented anti-modernists." 11 The most sophisticated example of this trend can be found in the work of Şerif Mardin, who sees in Kemalism a revolution above all against the "values" of the Ottoman ancien régime. ${ }^{12}$ Mardin would not approve, however, of the assumption of a clean break between the Kemalist and non-Kemalist value systems which has been carried to crude extremes to paint in broad strokes caricatures of Kemalist politicians and intellectuals versus caricatures of right-wing, Islamist, conservative figures, imposing predetermined, imaginary templates of thought and behavior on all. Legions of Kemalist and non-Kemalist academics, authors, journalists, and public intellectuals embraced those stereotypes and kept them alive, hiding from view the seething heterogeneity within both camps. We argue that, despite her reputation for being a typical right-winger of the Cold War years, Ayverdi was a hybrid character who belonged to and lived in both worlds at the same time. Ayverdi's case invites us to reevaluate dominant figures of the early republican and Cold War Turkey in search of heterogeneity and hybridity.

In responding to these questions, we attempt to uncover the multiplicity and complexity of Islamic identities in Turkey as well as reassess the concept of conservatism in a society which underwent tremendous change throughout the 20th century. The fact that we are dealing with an outspoken woman intellectual introduces an important twist to the discussion of both Islamism and conservatism.

\section{Introducing the heroine}

Sâmiha Ayverdi was born in İstanbul in 1905 into a well-connected, well-to-do family of Ottoman bureaucrats. ${ }^{13} \mathrm{Her}$ father and paternal grandfather served in the Ottoman army as middle-ranking officers,

11 Nazım İrem, "Turkish Conservative Modernism: Birth of a Nationalist Quest for Cultural Renewal," International Journal of Middle East Studies 34 (2002), 87.

12 Şerif A. Mardin, "Ideology and Religion in the Turkish Revolution," International Journal of Middle East Studies 2 (1971), 202.

13 The only academic study on Sâmiha Ayverdi in western languages is Nazlı Kaner's Sâmiha Ayverdi (1905-93) und die osmanische Gesellschaft (Würzburg: Ergon Verlag, 1998). All other works in Turkish have been written by followers or sympathizers and are mostly published by the family-founded and led Kubbealtı Foundation; see Kazım Yetiş, Sâmiha Ayverdi: Hayatı ve Eserleri (Ankara: Kültür Bakanlığı, 1993); Altan Deliorman, Işıklı Hayatlar (İstanbul: Kubbealtı, 2004); Aysel Yüksel and Zeynep Uluant, Sâmiha Ayverdi (İstanbul: Kültür Bakanlığı, 2005); Hicran Göze, Mâveradan Gelen Ses (İstanbul: Kubbealtı, 2005); Ergiydiren, Hayâli Cihan Değer. 
while her mother was descended from a family of more established civil bureaucrats. The family home was located in Şehzadebaşı in the heart of İstanbul's Old City. Memories of the Muslim neighborhoods within the ancient city walls and the daily life she witnessed in the mansions of the upper class İstanbulites in her youth would become recurring themes in her novels. She graduated from a girls-only high school, but her father saw to it that she received private instruction at home and learned French. She married very young, at the age of 16 , and gave birth to a daughter. Her biographers and her own memoirs are inexplicably silent about this marriage, which fell apart, ending in divorce by the time she was 21 .

Ayverdi returned to her family home with her daughter and never married again. The personal disaster in her life overlapped, on the one hand, with the traumatic downfall of the Ottoman Empire, and, on the other, with the birth pangs of republican Kemalism, for which she and her family had mixed feelings. It must be around this time that she fell genuinely under the influence of Kenan Rifaî, who acted as a spiritual anchor at a time of personal and political catastrophe. The sheikh had long-established, close contacts within her extended family: Sâmiha's niece and close friend Semiha Cemal had been a devoted follower, and her maternal uncle Dr. Server Hilmi Bey was one of the designated halifes (successors) to Rifaî. As if to respect a family tradition, Sâmiha's mother, elder brother, and Sâmiha herself all joined the Rifaî order and remained faithful to their master even after the Turkish republican regime outlawed all Sufi orders and banned the performance of rituals at dervish lodges.

The large number of women disciples in the circle of Rifaî fed rumors that the handsome, middle-aged sheikh abused religion for female company ${ }^{14}$ Members of the circle, however, disregarded gossipmongers and continued to hold regular meetings of mystical union. Throughout the 1940s, they attracted the attention of the İstanbul literati, who tried to gain access to the sheikh through Ayverdi, his most famous disciple. ${ }^{15}$ The end of the ultra-secular single-party regime in Turkey after World War II and the coming to power of the center-right Democrats in the 1950 general elections must have encouraged the Rifaî order and

14 Elderly sheikhs taking advantage of young women were familiar characters in the early republican Turkish novels. Yakup Kadri Karaosmanoğlu's Nur Baba stands as the outstanding example of that genre. On the other hand, the plot of and characters in a 1952 novel by Refik Halid Karay, one of the best-selling authors of the time, seem to be describing Kenan Rifaî and his circle; see Karay's Kadınlar Tekkesi, $2^{\text {nd }}$ ed. (İstanbul: İnkılap, 1999). 
Ayverdi to seek further visibility. Eventually, the circle came out of the shadows with the publication in 1951 of Kenian Rifầ ve Yirminci Asrin Işı̆̆ında Müslümanlik (Kenan Rifaî and Islam in the Twentieth Century), co-authored by Ayverdi and three other women from the circle, Safiye Erol, Nezihe Araz and Sofi Huri. ${ }^{16}$ The book was meant to eulogize the Sufi master, who passed away only a year before the book was released, and to introduce his idiosyncratic interpretation of Islam to Turkish readers. While the book attracted the attention of leading Orientalists in Europe, it was also immediately hailed in the Turkish press as a great example of female devotional literature in which many observers from conservative right to secular left found "the right path" to a "modern" understanding of Islam. ${ }^{17}$ If Ayverdi had previously been known to Turkish readers as a novelist, this book established her reputation as one of the intellectual leaders of the Turkish right.

From this point on, we see Ayverdi at the forefront of conservative and Islamist activism. With indispensable support from her brother, Ekrem Hakkı Ayverdi, ${ }^{18}$ a businessman who made a small fortune from building contracts, she set about rehabilitating the Ottoman past in a hostile, republican milieu. From 1950 onwards, she participated in the activities of the İstanbul Fetib Cemiyeti (The İstanbul Conquest Society) to commemorate the $500^{\text {th }}$ anniversary of the Ottoman conquest of İstanbul. Since the beginning of the republican era in 1923, this was the first Ottoman-related project on a mass scale, involving panel meetings, symposia, individual lectures, and the publication of İstanbul and Ottoman-related books, pamphlets, and journals. Sâmiha's brother Ekrem Hakk1 was elected the chairman of the society in 1953. The two then founded Yahya Kemal Enstitüsü (The Yahya Kemal Institute) in 1958 with the aim of publishing a critical edition of the poet's complete works and Istanbul Enstitüsü (The İstanbul Institute) to support research on the city and particularly its architecture. The choice of İstanbul as one center of their activities and the poet Yahya Kemal, whose neoclassicist verse celebrated the former Ottoman capital, as another signaled a personal dedication to reviving Ottoman culture, which the early republic had attempted to rub out. Ayverdi also worked behind the scenes-possibly with the help of her close friend, the Democrat Minister of Education, Tevfik İleri-to restart the Mevlevi Şeb-i Arûs ceremony in Konya in

\footnotetext{
Ayverdi et al., Ken'an Rifâî.

Deliorman, Işıkı Hayatlar, 181-4.

18 İsmet Binark, Ekrem Hakkı Ayverdi Bibliyografyası (İstanbul: Kubbealtı, 1999); Aydın Yüksel, Ekrem Hakkı Ayverdi (Ankara: Kültür Bakanlığı, 1993); Ekrem Hakkı Ayverdi Hâtıra Kitabı (İstanbul: Fetih Cemiyeti Yayınları, 1995).
} 
1953 after a hiatus of two decades. ${ }^{19}$ Her penchant for founding private societies and institutions to promote conservative and Islamist causes would bear its most important fruit in 1970 with the establishment of the Kubbealt 1 Cemiyeti (The Kubbealtı Society), which later evolved into a foundation and an academy. ${ }^{20}$ As its leading spirit, Ayverdi intended the Kubbealtı to become a rallying point for all right-wing intellectuals in Turkey where they could dig in and combat the rising leftist tide. Although she did not herself join the Aydınlar Ocağı (The Intellectuals' Hearth), another society with parallel aims, her brother became a founder and supporter. ${ }^{21}$

The polarized atmosphere and street violence in Turkey in the 1970s convinced her to become more involved in politics, which she did by penning and sending reports to prime ministers, ministers of education, and even chiefs of the general staff. ${ }^{22}$ In her letters and reports, Ayverdi drew attention to the Soviet Union as the root cause of all of Turkey's current problems and recommended a state policy to educate a future generation of teachers, professors, and intellectuals in nationalist and Islamic ideals as the only way to counterweigh communist propaganda and to win the hearts and minds of Turkish youth. When street fighting spiraled out of control towards the end of the 1970s, and civil war broke out between left-wing and right-wing militants, she encouraged her close associates to join the ultra-nationalist Milliyetçi Hareket Partisi (MHP or Nationalist Action Party). ${ }^{23}$ One of them, Agah Oktay Güner, became Minister of Culture on the MHP ticket during the coalition government of 1977-78, to the chagrin of the MHP grassroots, who considered him a dubious upstart.

Parallel to those activities, from the 1950s onward, Ayverdi also maintained a private salon where right-wing academics, intellectuals and İstanbul's surviving underground Sufis intermingled with lesser-known figures from her Rifaî circle. The usual theme of those gatherings was tasavvuf, the mystical interpretation of Islam, seen from the particular angle of Kenan Rifaî's teachings. The guests were often treated to a live performance of Turkish classical music and sometimes Sufi rituals and prayers. ${ }^{24}$ This rather private network of devotees came to include West-

19 Ergiydiren, Hayâli Cihan Değer, 114-19.

20 More information about the institutes and the academy can be found on their websites, www.istanbulfetihcemiyeti.org.tr and www.kubbealti.org.tr.

Sema Basmacı, “Aydınlar Ocağı ve Türk-İslâm Sentezi: 1980'lerden 200'li Yıllara Devreden MilliyetçiMuhafazakar Bakiye" (Unpublished MA Thesis, Hacettepe University, Ankara, 2009). 
ern academics visiting Turkey, such as Otto Spies, André Duchemin and Annemarie Schimmel, whom Ayverdi befriended and impressed as the "modern" face of Islam. ${ }^{25}$

After the 1980s, the now elderly Ayverdi retreated gradually from public life. Although this withdrawal from the role of a public intellectual could partly be attributed to the deterioration of her health, there is no doubt that this was also due to seeing her long-term goals accomplished. The 1980 military coup d'etat crushed all political activists in Turkey, but especially those on the left against whom Ayverdi had been struggling for decades. Adding to her sense of fulfillment, the military regime from 1980 to 1983 and the Özal Governments until the early 1990s embraced a synthesis of Islam and Turkish nationalism as their cultural policy (the so-called Türk-İslam Sentezi), ${ }^{26}$ whose intellectual roots can be traced back to the Kubbealtı and Aydınlar Ocăg circles. Having witnessed the end of the Cold War in the 1980s, a decline in the appeal of the socialist ideology, and Soviet Russia's loss of superpower status, Sâmiha Ayverdi died a contented public intellectual and a loyal dervish in 1993 at the ripe age of 87.

\section{Islam, mysticism, and elitism}

Sâmiha Ayverdi's approach to Islam could best be described as unorthodox. Her peculiar Islamic identity was shaped under the influence of what she thought to be catastrophic changes in Turkish society. The fall of the Ottoman Empire she lamented and the super-westernization $^{27}$ of the early republican period she criticized were two developments which left their imprint on her works. Like so many other Turkish women of her generation, Ayverdi led a double life in two different worlds. Her nostalgia for the fading memory of the Ottoman civilization and standing as a conservative, Islamist public intellectual did not prevent her from absorbing many key assumptions of the Kemalist reformers as inevitable requirements of modern life. It was this ideologically ambidextrous career that allowed her to speak to two different worlds at the same time.

25 Ergiydiren, Hayâli Cihan Değer, 184, 275-6; Ayverdi, Mülâkatlar, 107-12.

26 Bozkurt Güvenç et al., Türk-İslam Sentezi (İstanbul: Sarmal Yayınları, 1994); Vecihi Timuroğlu, 12 Eylül'ün Eğitim ve Kültür Politikaları (Ankara: Başak Yayınları, 1991); Etienne Copeaux, Espaces et temps de la nation turque: analyse d'une historiographie nationaliste, 1931-1993 (Paris: CNRS, 1997); Sam Kaplan, The Pedagogical State: Education and the Politics of National Culture in Post-1980 Turkey (Stanford: Stanford University Press, 2006).

27 Şerif Mardin, "Super-Westernization in Urban Life in the Ottoman Empire in the Last Quarter of the Nineteenth Century," in P. Benedict, E. Tümertekin and F. Mansur, eds., Turkey: Geographic and Social Perspectives (Leiden: Brill, 1974), 403-45. 
Unlike many in the Sufi tradition, who paid hardly any attention to organized religion and often regarded members of other faiths as fellow seekers of sacred truth, Ayverdi did not believe in multiple paths to God. From her point of view, Islam was the concluding chapter of the Abrahamic tradition and the Koran contained the final and definitive word of God, superseding all prior revelation. In her contact with representatives of other faiths, for example, she was respectful but distant, establishing an implicit hierarchy of religions. ${ }^{28}$

However, Ayverdi was also at variance with the majority of other conservative Islamists in Turkey with respect to the "correct" interpretation of Islam, both as a legal corpus of norms and as lived experience. Throughout her life, Ayverdi fought against what she alternatively called the "fanatic" or "Wahhabi" approach to Islam, which reduced God's message via his messenger Muhammad to a "desert religion" only. ${ }^{29}$ In a way, she was repeating the classical Sufi argument in the ancient debate between the Sufi, or Muslim mystic, and the zabid, the pious and philistine bigot. Whereas the zahid delved into hair-splitting sophistry and preached fallaciously subtle observance of religious law, the Sufi maintained that the "true" message of Islam is not about how to dress, what to eat, or when to pray. Moral integrity, righteousness, and suppression of the self in order to connect with God are values, from the Sufi perspective, that constitute the core of the Islamic belief system; as much as the "exterior" rituals and practices are central to Islamic identity, they are, nevertheless, secondary in importance when compared to the "interior" enrichment of the Muslim.

Ayverdi established herself firmly on the Sufi side of this debate. On the one hand, she was a practicing Muslim: autobiographical material in her works and recollections of people in her circle show that she performed the five daily prayers (namaz) and fasted in the month of Ramadan. Occasionally, she was approached by early republican intellectuals who had ceased to be practicing Muslims but who nevertheless wanted to maintain a spiritual bond with God and thought that this could be possible within the supposedly relaxed Sufi framework. Ayverdi's response to such entreaties was always negative; she did not approve of a vision of Islam without sharia. ${ }^{30}$

On the other hand, Ayverdi remained bitterly critical of the proverbial zahid and particularly his contemporary incarnations. As a matter

28 Ayverdi, Mülâkatlar, 107-9.

29 Sâmiha Ayverdi, Bă̆ Bozumu (İstanbul: Kubbealtı, 2005), 255; Ayverdi, Ah Tuna Vah Tuna (İstanbul: Kubbealtı, 2004), 315; Ayverdi, Millî Kültür Mes'eleleri ve Maârif Dâvâmı, $3^{\text {rd }}$ ed. (İstanbul: Kubbealtı, 2006), 55, 107, 377-9; Ayverdi, Mülâkatlar, 312-13. 
of fact, Ayverdi made numerous references in her work to unpleasant encounters with the zahid, a surprising phenomenon if we consider the otherwise pro-Islamic message of her books. One such unforgettable encounter took place when the twenty-five-year-old Sâmiha entered the women's prayer room in the Yeni Cami in İstanbul. In the middle of her prayer, she heard a male prayer leader shouting at her from behind; "Hey you! Tall lady!" the man said, "Turn a little bit to the right. You are not facing Mecca exactly" 31 Ayverdi thought the man's behavior was utterly inappropriate for a number of reasons: to begin with, one should not address a praying person and certainly not a woman praying in a designated area; second, it is unbecoming for a Muslim to expose mistakes of fellow Muslims; and finally, one faces God in all directions from the Sufi perspective, hence the irrelevance of the zahid's counsel. On another occasion, Ayverdi complained with great sadness that an elderly male member of her Rifaî circle was not permitted to lead the prayer in an İstanbul mosque, because the man had a gold tooth in his mouth. ${ }^{32}$ Taken together, all these encounters show how Ayverdi and her Rifaî circle felt indignant about being discriminated against at the hands of fellow Turkish Muslims who did not see eye to eye with them on many issues. In all likelihood, the tension stemmed from Ayverdi's insistence on belonging to two worlds - modern and traditional-at the same time, while the vast majority of devout Turkish Muslims refused to venture beyond tradition. This was especially the case when it came to the visible markers of modern life, particularly those concerning women, such as unveiling and gender equality.

To add another layer of complexity, class concerns also seem to have played an important role in Ayverdi's and her circle's attitude toward Islam. In early republican Turkey, the predominant discourse on Islamic rituals was to identify them as largely incompatible with the modern age. ${ }^{33}$ Almost everyone criticized reciting and even memorizing the Koran without understanding a word of it, and attempts were made in the 1930s to produce an authorized Turkish translation to be used in mosques. ${ }^{34}$ Similarly, in 1928, İsmayıl Hakkı Baltacıŏlu, a professor

31 Ayverdi, Bağ Bozumu, 250-1.

32 Ayverdi, Millî Kültür Mes'eleleri, 380.

33 On the question of Islam in republican Turkey, see Niyazi Berkes, The Development of Secularism in Turkey (Montreal: McGill University Press, 1964); Şerif A. Mardin, “Ideology and Religion," 197211; Binnaz Toprak, Islam and Political Development in Turkey (Leiden: Brill, 1981); İsmail Kara, Cumhuriyet Türkiye'sinde Bir Mesele Olarak İslam (İstanbul: Dergâh, 2008); İştar Gözaydın, Diyanet: Türkiye Cumhuriyeti'nde Dinin Tanzimi (İstanbul: İletişim, 2009); Beşir Ayvazoğlu, Tanrıdağı'ndan Hıra Dağı'na: Milliyetçilik ve Muhafazakarlık Üzerine Yazılar (İstanbul: Kapı Yayınları, 2010). 
of philosophy and public intellectual, penned a memorandum for religious reform which he published in daily newspapers and submitted to the Divinity Faculty at the İstanbul Darülfünûn to be discussed by religious authorities there. The memorandum focused on the problem of the "form" of prayers in the mosque, addressing complaints about "smelly feet"- one has to take off one's shoes when entering a mosque - or "pain" resulting from sitting cross-legged, or again the absence of music in the ritual. Baltacığlu's extravagant recommendations ${ }^{35}$ such as lifting the "shoe-ban," introducing benches and organs to mosques as in churches were not taken seriously and made fun of later on, but show the extent to which westernized Muslims were concerned with a perceived lack of decorum in Islamic rituals.

Ayverdi and her Rifaî circle could not have agreed more. More than anything else, they wanted to rescue Islam from its association with ignorant imams, shabby clothes, unseemly beards and veiled women of lower-class backgrounds, and once again to restore its prestige among the highborn İstanbul bourgeoisie. Worthy of a short digression at this point is the unexpected display of elitism and elitist views by the members of the Ayverdi circle; unexpected because many students of modern Turkish political history have labeled the Kemalist, early republican reformers as the period's elitists par excellence. The label has since stuck: the Kemalist reformers are usually regarded as an elite minority, cut off from the religious and cultural hinterland of their people; a minority whose condescending attitude toward the lifestyle of their own people and top-down methods of super-westernization alienated the Turkish masses. Faced with this paradigmatic linkage between Kemalism and elitism, it comes as a surprise to discover a very similar set of elitist views and arguments in the heart of the Turkish Right, which has nevertheless built a very strong anti-elitist discourse since 1945 as part of its overall critique of Kemalism.

As a typical conservative of her times, Ayverdi firmly believed that there could be no equality between human beings. ${ }^{36}$ She did not mean to say, of course, that the so-called "second-rate," incompetent," "inferior"

1999), 26-31, 63-79 and 92-110; Amit Bein, Ottoman Ulema, Turkish Republic: Agents of Change and Guardians of Tradition (Stanford: Stanford University Press, 2011), 127-8.

36 It might well be argued that Turkish conservatives had always been unabashed elitists, that is, until a major change of heart in the 1980s, after which they adopted a more egalitarian discourse to challenge the privileged status of the Kemalist establishment. If so, what is paradoxical about Ayverdi's elitism? The paradox is in the behavior of the contemporary generation of Turkish conservatives, who are trying to sweep conservative elitism of the former generations under the carpet and to reimagine Turkish conservatism as an egalitarian movement from the beginning. We owe this point to Ali Yaycığlu. 
individuals should be denied their basic human rights, but, rather, that everyone should know and accept his or her proper place in an essentially hierarchical society. From Ayverdi's point of view, respect for competence and aptitude in an Islamic society would pave the way for the formation of meritocratic classes, among which the best policy would be to pursue a harmonious balance rather than insisting on an "unjust" and, hence, disruptive policy of egalitarianism. ${ }^{37}$ When confronted in her private salon by a socialist guest (a curious Çerkes Hasan), who wanted to make the Turkish peasant the new ruler of the country, Ayverdi responded thus:

Ayverdi: With his improper clothes [Çarı̆ğ ile, postu ile mi]?

Ç. Hasan: Of course.

Ayverdi: Would you, then, drag your cook from out of the kitchen and entrust him with the administration of your household?

Ç. Hasan: Why not? Is he not a human being?

Ayverdi: No doubt he is, but he must have been raised to run the kitchen, not to take care of the daily chores of a household. There is certain portion of the peasants who are to remain peasants and yet another portion who could be educated to assume political responsibility. ${ }^{38}$

Taking our cue from such statements, it is not difficult to see why Ayverdi preferred the Ottoman Empire to the Turkish Republic. With its society compartmentalized along religious, professional, and gender lines, the Ottoman Empire was a typical example of a society of orders until the Tanzimat reforms of the nineteenth century, and perhaps even after. The republic, on the other hand, was established with the promise of equality for all and, although this promise was not exactly fulfilled for many groups, it did initiate a more participatory system.

Ayverdi's elitism was shared by other members of her circle, too. Being descendants of the late Ottoman military/civilian bureaucratic elite, these young women were deeply conscious of their class and social status, which was under attack from two quarters simultaneously: for the Kemalists, they were too Islamic and Ottoman; for the traditional majority, too modern and westernized. The clash of identities is particularly apparent in the story of Safiye Erol's visit to a mosque:

37 Ayverdi, Mülâkatlar, 238-40.

38 Ibid. 
Safiye Erol: Yesterday there was a mevlud ceremony for one of our friends [...] I do not go to the mosque very often; not because I do not feel like it, but in our society the issue of mosque attendance, for instance, the issue of attire has not been solved yet. It has become more likely today that the poor people, the elderly, I do not want to put it that way, but only that kind of people are going to the mosque. This is not because the younger generation or the wealthy do not feel the need to; they do, but nevertheless they cannot go, because they are not received well. Yesterday, I made an effort to pick the right kind of clothes because I was going to the mosque. I did not put on make-up, but I did my hair, wore a beautiful black dress, covered my hair with black chiffon [siyah bir tül], and took with me a pair of unworn suede shoes. I did not want to go to the mosque wearing silly [şapşal] clothes or enter [barefoot] with my stockings. As I entered the building, I put my shoes in a bag and wore the new pair. At that moment, he must have been the caretaker or the müezzin of the mosque, a man talked to me in very strong language and said:"Hey madam, look, you cannot enter with your shoes on." I told him that this pair was clean, but he did not understand. Then I said, "When the mevlud is over, I will talk to you outside." [...] But I cried so much during the mevlud ceremony that I forgot to do that on my way out. Now, look, isn't it so inappropriate to scold someone like this in the spiritual atmosphere of the mosque?

S. Ayverdi: He is not to be blamed; he has been abandoned at that level. He has not been educated to understand you. ${ }^{39}$

There are several observations to be made about this encounter between Safiye Erol and the mosque official. Firstly, for all her mystical religiosity which made her cry so much at the mevlud, Erol did not feel at home in the mosque, because she could not bond with "that kind of" fellow Muslim. Apparently, the dislike was mutual. This left Erol with no choice but to seek spiritual fulfillment within the elite Ayverdi circle. Secondly, the republican setting and Erol's class status worked in her favor this time and empowered her because, although the mosque official warned Erol 
harshly, he could not stop her and had to watch helplessly as this upperclass woman simply walked in with her "suede shoes," "beautiful black dress," and "black chiffon" scarf to join the ceremony.

Sâmiha Ayverdi's embrace of an elitist worldview is also evident in her writings on the Turkish education system, of which she was extremely critical. What bothered her most were the literacy campaigns of the early Republican People's Party (CHP) and Democratic Party (DP) governments. According to the 1926 census, the proportion of Turkish citizens who could read (but not necessarily write) did not exceed 10 percent, ${ }^{40}$ but by the 1950 s that figure had reached some 35-40 percent. ${ }^{41}$ Literacy campaigns were pursued with vigor by the DP as part of its policy of reaching out to the Turkish countryside and increasing the standards of living in Turkish villages. The center-right DP considered literacy the key instrument in integrating rural labor into Turkey's ambitious industrialization program. The new philosophy of education, tailored according to such concerns, was approved at the National Education Congresses in 1953 and 1957.42

It was precisely this that Ayverdi disagreed with. She wrote a series of articles for the pro-DP daily Havadis criticizing the government policy of giving priority to increasing literacy levels. ${ }^{43}$ When the first article in this series was published, the editor of Havadis received a call from none other than President Celal Bayar, who asked that publication be discontinued. ${ }^{44}$ In that series and elsewhere, Ayverdi provided an overall critique of the right-wing policy of dealing with and investing mainly in the economy, agriculture, physical infrastructure, trade and technology, while ignoring "the most important capital: human beings." ${ }^{5}$ Teaching everyone how to read and write was an impossible task, she argued, and not desirable either because it upset her vision of a delicate balance of power between meritocratic classes. She argued that this policy amounted to feeding "weeds to a carnivore and meat to an herbivore" (Et yiyenin önüne ot, ot yiyenin önüne et koymak), ${ }^{46}$ and was not advantageous for Turkey:

40 Başvekâlet İstatistik Umum Müdürlüğü, Millet Mektepleri Faaliyeti İstatistiği, 1928-33 (İstanbul: Devlet Matbaası,1934), introduction.

41 W.C. Brice, "The Population of Turkey in 1950," The Geographical Journal, 120 (1954), 351.

42 Milli Eğitim Bakanlığı, Maarif Şuraları, 1939-1981, 10 vols. (Ankara: Milli Eğitim Bakanlığı, n.d.).

43 Ayverdi was not alone in thinking along those lines. Publications by another prominent figure of the Turkish Right, Professor Mümtaz Turhan, were probably her source of inspiration. See, Mümtaz Turhan, Maarifimizin Ana Dâvaları ve Bazı Hal Çareleri (İstanbul: İstanbul Yayınevi, 1954). Ayverdi, Millî Kültür Mes'eleleri, 93.

Ibid., 19.

46 Ibid., 87. Our thanks to Talât Halman for translating this phrase and partly capturing the rhyme of the Turkish original. 
The right kind of solution is not in multiplying the number of schools, nor in a literacy campaign to spread low-quality education, but in the national and moral spirit transmitted by the existing and future schools. Without that [spirit], it might perhaps be considered more useful for the country to leave society to its oral culture only. This is because an education policy which is not informed by national-moral values might seem to succeed on the surface, but in reality would tear apart and devour the souls just like wild beasts of prey. ${ }^{47}$

Instead of wasting Turkey's scarce resources on what she deemed an extravagant project of attaining universal literacy, Ayverdi's alternative recommendation was to shift priority to educating a new generation of Turkish intellectuals, brought up as living specimens of the "national and moral spirit." This new generation - not to be confused with the "degenerate" products of the first few decades of the Kemalist revolutionwould, in turn, pass on their learning and values to the rest of the society. To put it differently, Ayverdi's proposal was none other than Kemalism in reverse; a top-down process of illuminating the masses with the help of a vanguard class of elite intellectuals. True, Ayverdi expected those intellectuals to be bearers of a decidedly un-Kemalist, national-Islamic set of values; yet, her vision of reform simply prolonged, rather than put an end to, the age-old elites-versus-masses cleavage in late Ottoman and early Republican politics. ${ }^{48}$

\section{Blurring borders: Assessing Sâmiha Ayverdi's place in Turkish literary history}

Though Ayverdi's intellectual influence on the Turkish Right was significant, her literary works have been ignored by mainstream literary critics, a detail which did not escape the attention of Western Orientalists who discussed her work. In an article, published half a century ago, Annemarie Schimmel, the German Islamologist, remarked that Ayverdi had been snubbed by major literary reviews such as Varlik and Yeditepe, ${ }^{49}$ which dictated the literary agenda of the time. As the Turkish publishing world was divided along ideological lines between national-conservative and liberalleft circles, it is not really surprising that liberal-left critics shunned Ayverdi's works. ${ }^{50}$ But conservative literary critics and historians have not taken

47 Ibid., 28 .

48 Şerif Mardin, "Center-Periphery Relations: A Key to Turkish Politics?" Daedalus 102 (1973), 169-90.

49 Annemarie Schimmel, "Eine Istanbuler Schriftstellerin," in Wilhelm Hoenerbach, ed., Der Orient in der Forschung: Festschrift für Otto Spies zum 5. April 1966 (Wiesbaden: Harrassowitz Verlag, 1967), 569. It is interesting to note that in a context of growing interest in Turkish in the Western world in the 
her literary work seriously either and have written little about her apart from occasional laudatory texts. One could argue that the shallowness and repetitiveness of her neo-mystical coming of age novels and platonic romances has not been conducive to passionate and enlightened criticism. Even a sympathetic literary historian and critic such as Orhan Okay wrote that she did not "problematize narrative technique." 51 This, however, is a point that needs to be reconsidered in order to uncover Ayverdi's originality in the context of 20th century Turkish literary history. While her early novels subvert the conventions of mystical love epics by inverting gender roles, these narratives as well as her later memoirs and essays, which were written at a time when she advocated increasingly racist and radical religious ideas, challenge Western notions of fiction and autobiographical writing. Her works thus question both traditional Ottoman-Turkish and modern Western generic assumptions.

Ayverdi wrote little about her own conception of literature and the creative process. She mostly confined herself to general declarations on the need for an engaged literature which did not sideline aesthetic concerns. Her lack of interest in literary criticism is surprising since she pontificated on a wide range of matters after Kenan Rifaî's death. The few pieces she wrote on literature were usually biased and displayed a lack of literary sensitivity. In Dost (The Friend, 1980), a hybrid text about Kenan Rifaî and Islam, she implicitly compared her spiritual leader to the mystical poets Yunus Emre and Rumi (Djalâlu'd-dîn Rûmî).52 Though it might be legitimate to discuss the continuity between the teachings of the great Anatolian mystics and those of Rifâî, Ayverdi remained oblivious to the fact that both Yunus Emre and Rûmî had had an impact on the development of their respective literary traditions, which was far from being true in her mentor's case. More significant is her attempt to develop a counter discourse rejecting the denigratory assessments of classical Ottoman culture, which were quite common in the mainstream literary world. ${ }^{53}$

Her mystical coming of age novels could be read as modern takes on the central topic of mystical love epics - the passage from human

aftermath of Orhan Pamuk's Nobel Prize, recently published studies on Turkish literature such as Azade Seyhan's Tales of Crossed Destinies: The Modern Turkish Novel in a Comparative Context (New York: Modern Language Association, 2007) and Nergis Ertürk's Grammatology and Literary Modernity in Turkey (New York: Oxford University Press, 2011) have espoused the liberal status quo and shun Ayverdi's works as well as Islamist literature in general.

53 Her portrait of Mehmed II, the Conqueror as a poet is revelatory of her concerns: Sâmiha Ayverdi, Edebi ve Manevî Dünyası İcinde Fatih (İstanbul: İstanbul Fetih Derneği, 1953). 
to divine love. A common theme in her novels is the impossible and, hence, unconsummated love between a young woman and a charismatic, middle-aged man, both of whom are married to other people. Platonic love, often illicit, is celebrated as it becomes a gateway to the discovery of true, divine, love. The novel Yaşayan Ölü (The Living Dead, 1942) can be interpreted as a variation on the theme of "dying before you die," a central idea in the Sufi doctrine based on one of Muhammad's sayings. The main character Leyla's realization, after several predicaments, that "living without dying is but a long agony," 54 implying the need to abandon worldly desires in order to unite with the divine beloved, is also shared by characters in Ayverdi's other novels. Seniha in Son Menzil (The Last Station) discovers that "the human being is nothing but a station on the road to love $[. .$.$] a station which must not be stopped at, but which must$ be passed, a bridge which leads to the truth." 55 Aliye in Batmayan Gün (The Un-setting Day) and Adli in Yolcu Nereye Gidiyorsun (Traveler, Where Are You Going, 1944) share similar mystical experiences. One could argue that Ayverdi's mystical appropriation of the novel, and of modern settings for her texts, is, ideologically, on the same level as the modernized mystical love epics of Islamist poets. Necip Fazıl Kısakürek and Sezai Karakoç, while embracing all the possibilities of modern and modernist poetry respectively, developed a neo-mystical discourse in their modern mesnevis. ${ }^{56}$ For Ayverdi, the fusion of the modern form with the mystical content conveyed a political message pertaining to the relevance of her twentieth-century religious engagement. That both male and female characters attain mystical fulfilment is a distinctive feature of Ayverdi's novels, unseen in the works of male Islamist poets, and indicates her advocacy of a greater involvement of women in Islamic civil society. In Ayverdi, the Mecnûn, the possessed lover of the classical tradition, has become a Mecnûne, an infatuated young woman, defying social conventions and discovering divine love.

Perhaps more than her subversion of the classical tradition, it is her challenge to Western and westernised literary conventions that deserves the greatest attention. A case in point is her final novel, İbrâbim Efendi Konağı (The Mansion of Ibrahim Efendi, 1964), a work that critics and historians have not been able to shelve unanimously in a well-defined literary category. Characteristically, Ayverdi herself stressed in a short foreword that "this book [was] neither a story nor a fairytale, nor [was]

Sâmiha Ayverdi, Yaşayan Ölü (İstanbul: Kubbealtı, 2005 [1942]), 198.

Sâmiha Ayverdi, Son Menzil (İstanbul: Kubbealtı, 2007 [1943]), 241-2.

56 On the modern mesnevi, see Laurent Mignon, Çağdaş Türk Şsiirinde Aşk Aşıklar Mekânlar (Ankara:

Hece, 2002), 129-49. 
it a novel," but that "90 percent" of the related events were true. ${ }^{57}$ Though she emphasizes the story's veracity, including reprinted documents such as photographs of characters and of their tombstones, this narrative is a barely disguised allegory of the demise of the Ottoman Empire. At the end of the novel, the narrator concludes that the downfall of the family of İbrahim Efendi, a historical character who was president of the Treasury Commission, "occurred at the same time as the demise of a colossal civilization." 58

The ambiguity between fiction and memoir is cultivated in earlier works as well by both the author and her publisher. In a foreword to the short-story collection Mabette Bir Gece (A Night in the Shrine, 1940), one of her earliest published works, the publisher underlined that the "stories were taken from real life,"59 echoing thus the words of the male narrator of one of the short-stories who explains that he is about to reveal, "not a tale, but a simple page torn from the book of [his] life." ${ }^{60} \mathrm{Be}$ side paratextual clues, Ayverdi also applied narrative strategies that blur the borders between fact and fiction, such as the use of a first person narrator-in several short stories in Mabette bir Gece and the novels Ateş A ğacı (The Tree of Fire, 1941), Insan ve Şeytan (Man and Satan, 1942), Yaşayan Ölü (The Living Dead), Yolcu Nereye Gidiyorsun?-inducing a confessional mood that emphasizes the verisimilitude of the related events. Another, related, strategy was her choice of the partly epistolary novel form (Yaşayan Ölü) which allowed greater realism by describing even the most trivial details of everyday life. Nevertheless, it must be said that Ayverdi avoided any exploration of the more intimate aspects of daily life.

The ambiguity that she seemed to cultivate in her novels and shortstories becomes meaningful in the context of the debates on literary realism which were raging in Turkey in the 1940s and $1950 \mathrm{~s} .{ }^{61}$ Both Kemalist advocates of village realism and leftist socialist realists defended visions of literature and society that Ayverdi did not subscribe to. The quest for realism in itself had its roots in the rejection of the Ottoman classical literary tradition by the main theoreticians and practitioners of post-Tanzimat literature. By continuously challenging readers' minds as to the veracity of the narrated events in her fiction, Ayverdi was both

57 Sâmiha Ayverdi, Ibrahim Efendi Konağı (İstanbul: Kubbealtı, 2009 [1964]), 7.

58 Ibid., 429.

59 Quoted in Okay, "Takdim."

60 Ayverdi, Mabette Bir Gece, 44.

61 See, among others, Seyhan, Tales of Crossed Destinies, 80-134; Kemal Karpat, "Social Themes in Contemporary Turkish Literature," The Middle East Journal, 14 (1960), 29-44 and 154-68. 
defying the still, at the time, sacrosanct distinction between fact and fiction and questioning contemporary understandings of literary realism. By doing so, she was confronting not only the Kemalist and progressive Turkish literary intelligentsia, but also Western realist tradition.

Generic hybridity, a defining aspect of her fiction, is also a useful conceptual tool when analysing her memoirs. Even though she wrote nine novels between 1938 and 1964-seven of those published by 1944she later abandoned the genre altogether, focusing on autobiographical narratives from 1974 onwards. By 1990 she had published ten works categorized as "memoirs." More were added to this list posthumously. Though her entourage encouraged her to do so, Ayverdi, never published a full autobiography. Her numerous collections of memoirs consist of short autobiographic or sometimes biographic sketches, which are only loosely linked and can be read independently. Some of those sketches read like morality tales and have little in common with autobiography or confessional writing but are much closer to religious parables. Reminiscences often serve simply as an excuse to discuss historical events. Thus, she inverts the traditional aims of autobiographical texts where a particular historical context serves as the background for the development of the subject's personality. In her texts, the recollection of the personal past serves as an excuse to dwell on history. Hence, her selective vision of history is on the same discursive level as her recollections of the past. It therefore becomes difficult to explore the soundness of her interpretations without also questioning the veracity of her personal memoirs, or, in other words, to discover whether she is respecting the autobiographical pact with her readers. Western generic norms are thus challenged once again.

In recent years, several Turkish works that could be categorized as "autofiction," that is to say fictionalized autobiographies in various guises, have been translated into English. Anglophone readers may thus easily be misled into believing that narratives of the self have always been a major genre of Turkish literature. At the time Ayverdi was writing, however, it was unusual for a woman from a conservative background to dwell on personal aspects of her life in autobiographical writings and thus to challenge the frontiers between the public and the private. Indeed, memoirs, autobiographies, and auto-fictional texts expose the private sphere and the intimacy of the narrator; a move which was frowned upon in Ottoman Turkish society, particularly if the narrator was a woman. There were, however, a few exceptions before Ayverdi. ${ }^{62}$ The

62 Halide Edip Adıvar, the renowned novelist and political activist, published her Memoirs in English as 
autobiography of Fatma Aliye, one of Ottoman Turkey's first woman novelists, co-written by herself and Ahmed Midhat Efendi, an influential novelist and publisher, is a case in point. It is striking, however, as Hülya Adak noted in her study of this hybrid text which merges biography and autobiography, that Fatma Aliye ceases to be the narrator of her own life once she reaches the recollection of her adolescence. Ahmed Midhat Efendi takes over as the narrator, ignoring the private sphere of her life, precisely because exposing the privacy of a woman is not acceptable. ${ }^{63}$

In the Turkish context, memoirs (anı or hâtırat) and, in particular, autobiography, are relatively new genres which emerged in the second half of the 19th century as a result of the appropriation of Western literary genres, and are thus arguably a product of modernity par excellence. Indeed, French literary critic Philippe Lejeune ${ }^{64}$ has claimed that it would be anachronistic or irrelevant to look for autobiographies before 1770 or beyond the narrow borders of what he calls Europe. ${ }^{65}$ Nevertheless, such restrictive views have been challenged on a variety of grounds by literary theoreticians and historians (among others) in the context of debates on the troublesome concept of "autofiction" 66 and also by scholars working on Middle Eastern literatures. Dwight F. Reynolds has argued in favour of a more inclusive redefinition of the notion of autobiography, ${ }^{67}$ which would, nonetheless, be more rigorous than Bernard Lewis's claim that the continuous thread of self-narratives in near-eastern literature

early as 1926 and The Turkish Ordeal, another autobiographical text, two years later. Selma Ekrem, the granddaughter of the famous Young Ottoman intellectual Namık Kemal, published her English memoirs Unveiled: The Autobiography of a Turkish Girl in 1930. In this context, earlier, relatively popular, autobiographical texts in English, arguably catering for the expectations audiences in the English speaking world such as Melek Hanım's 1872 Thirty Years in the Harem and Zeyneb Hanım's 1913 A Turkish Woman's European Impressions (edited by the feminist Grace Ellison) might also be mentioned. The fact that these texts were in English indicates, however, that they functioned outside the realm of the Ottoman Turkish literary world.

63 Hülya Adak, "Gender-in (g) Biography: Ahmet Mithat (on Fatma Aliye) or the Canonization of an Ottoman Male Writer," Querelles: Jahrbuch für Frauen und Geschlechterforschung, 10 (2005), 7.

64 In Le pacte autobiographique (Paris: editions du Seuil, 1996 [1975]), a milestone in literary criticism, Philippe Lejeune, defying much of Foucauldian and post-Foucauldian cultural criticism, argues that the following criteria define autobiography: It is a prose narrative that has as its topic the development of the personality of an individual. The author (whose name refers to a real person) and the narrator are identical as are the narrator and the central character of the book. The narrative, moreover, has to be retrospective. He maintains that memoirs are distinct from autobiographies in the sense that they do not aim to narrate the development of a personality but focus on particular events in a life.

65 Lejeune, Le pacte autobiographique, 13-14.

66 For a summary of those discussions, see Jean-Louis Jeanelle, "Où en est la reflexion sur l'autofiction?," in Jean-Louis Jeanelle and Catherine Viollet, eds., Genèse et autofiction (Louvain-La-Neuve: Bruylant Academia, 2007), 17-37.

67 Dwight F. Reynolds, "Introduction," in Dwight F. Reynolds, ed., Interpreting The Self: Autobiography in the Arabic Literary Tradition (Berkeley, Los Angeles, London: University of California Press, 2001), 1-14. 
proves that autobiographical writing did not flourish as a result of Western influence, but had always existed. ${ }^{68}$ Despite its lack of methodological rigour, Lewis's statement was, back in 1991, a welcome probing of an age-old commonplace of orientalist scholarship. Susanne Erdewitz' later approach to Arab and Classical Arab autobiography is even more useful as a conceptual tool for literary historians, postulating that such autobiography's "stress on the person instead of the inner self, on situation instead of a coherent life story and on social instead of private (not to speak intimate) relations comes much closer to postmodern views of "selfhood" than traditional Western autobiography" 69 Debates over narratives of the self in the Islamic world and a less Eurocentric definition of the concept of autobiography have fascinating implications here. For instance, Mary Ann Fay describes the "articulation of the autonomous and recoverable self [...] in the Arab-Islamic world independently and much earlier than the 19th century influence of enlightenment principles among the Ottoman intelligentsia." ${ }^{70}$ Even so, it remains true that texts that aim principally at the narration of the self remain rare before the second half of the 19th century. ${ }^{71}$ Hence Ayverdi's emphasis on the autobiographical was exceptional in the Turkish context. Her challenge to generic conventions, on the other hand, was part of her struggle against what she called "Judah and the Cross."

\section{Fighting Judah and the cross}

While her approach to fiction signals her desire to challenge the generic conventions of the Western realist tradition, some of Ayverdi's narratives have a much darker side which has largely been ignored by critics in Turkey and internationally: the representation of ethno-religious minorities. Indeed, a whole range of stereotypes, from conniving Jewish merchants to lascivious Greek concubines and murderous Armenian partisans can already be encountered in her early works. After the 1960s, the non-Muslim minorities of the Ottoman Empire and Turkey would become one of the major themes of her essays and memoirs. ${ }^{72}$

68 Bernard Lewis, "First Person Narrative in the Middle East," in Martin Kramer, ed., Middle Eastern Lives: The Practice of Biography and Self-Narrative (New York: Syracuse University Press, 1991), 20-34.

69 Susanne Enderwitz, "Autobiography and Islam," in Olcay Akyıldız, Halim Kara and Börte Sagaster, eds., Autobiographical Themes in Turkish Literature: Theoretical and Comparative Perspectives (Würzburg: Ergon Verlag, 2007), 41.

70 Mary Ann Fay, "Introduction," in Mary Fay Ann, ed., Auto/Biography and the Construction of Identity and Community in the Middle East (New York: Palgrave, 2002), 2.

71 M. Orhan Okay, “Hâtırat- Türk Edebiyatı," İslam Ansiklopedisi, Vol. 16 (İstanbul, 1997), 446.

72 The representation of non-Muslims in Turkish literature is a growing field of investigation both in and outside Turkey. Herkül Milas' Türk Romanı ve Öteki (İstanbul: Sabancı Üniversitesi, 2000), a study of the representation of Greeks in the Turkish novel, is a milestone. See also, Seda Uyanık, "19. Yüzyıl 
Ayverdi wrote largely in response to Western discourses on Turkey. That the greatness of Ottoman civilization was not universally recognized was a continuous source of complaint in her writings and she saw it as one of her missions to enlighten Western nations.

The fight against Christian missionaries is part of her anti-imperialist struggle and has a particular importance. According to her, Christian missionaries constitute a major threat to Turkish identity and territorial integrity. In 1969, she even published her exchange of letters with Raymond Kern and Dale Rhoton, two North American Evangelical missionaries based in Switzerland. ${ }^{73}$ In the introduction to the work, she emphasized the threat posed by missionary activities and the role played by missionaries in the furthering of Western imperialistic policies. Hence, it comes as a surprise that, despite the importance she gave to this particular topic, she seemed to be ignorant of the differences between the various Christian denominations. She went as far as to write an open letter to Pope Paul VI to protest against the Evangelicals in Turkey, thinking that he must be behind their missionary activities. There is little doubt that, had he read this letter, the Bishop of Rome would have commiserated with her.

As part of this response to the West, she consciously inverts Western stereotypes on Islam and Ottoman Turkey in her essays on history: in one of her last articles, she wrote that "it is probably impossible to find another nation that could compete with the Turks in regard to justice and tolerance." 74 According to Ayverdi, the Ottoman Empire had been a haven for the oppressed throughout history; in an article on the seventeenth century Polish refugees, she wondered, "Whom haven't the Turkish lands embraced? All the persecuted burned with the desire to come to those lands." ${ }^{75}$ However Ottoman Turkey was not only a sanctuary for the victims of oppression, it had also a mission civilisatrice and brought peace and culture to the lands it conquered. Their inhabitants, whatever their religion or ethnicity, prospered thanks to the Pax Ottomana and shared the fruits of the Ottoman civilizing project. ${ }^{76}$ In several articles, Ayverdi emphasized that the source of Ottoman Turkish tolerance and civilizational greatness was Islam: "It is an unquestionable fact that the friendliness and the warmth shown to the minorities by

Osmanlı Türk Romanında Gayrimüslim İmgeler," (unpublished MA thesis, Bilkent University, Ankara, 2007).

73 Ayverdi, Misyonerlik Karşııında Türkiye (İstanbul: Kubbealtı, 2005 [1969]).

74 Sâmiha Ayverdi, Arkamızda Dönen Dolaplar (İstanbul: Kubbealtı, 2007), 35.

75 Ibid., 79.

76 Sâmiha Ayverdi, Kaybolan Anahtar (İstanbul: Kubbealtı, 2009 [2008]), 55. 
the Turks, almost unseen anywhere else in the world, originates in their faith." 77 Ayverdi's idealization of Ottoman rule, which has only a vague connection with historical reality, should be read in conjunction with her views on Christianity.

In Ayverdi's texts, Christianity is tyrannical and oppressive, while Islam is the religion of tolerance and moderation: "Christianity has made of the United States an unbendable fanatic," she wrote in an article on Turkish migrants. ${ }^{78}$ She argues that, while the Koran enjoins the faithful to be tolerant, the Bible orders its followers to brutalize and destroy the enemies of the faith. Her literal interpretation of the Hebrew Bible contrasts sharply with her more "hermeneutic" reading of the holy book of Islam. ${ }^{79}$ Here, too, she inverts Western accusations against the Koran, which suggest it is a book which nurtures fanaticism, violence, and hate, and turns them against the Bible. In this comparative framework, she also discusses the differences between Ottoman expansionism and Western colonialism; a recurrent theme of her non-fiction. In various articles, she stresses that European imperialism brought nothing but misery to Africans and native Americans. ${ }^{80}$ She denounces colonialism as a continuation of the crusades. However, her strident critique of slavery and imperialism should not be misread as an anti-racist stance. In an article attacking the growing interest in Afro-American music in Turkey, she condemns young musicians "who copy the wild black tribes of Africa" and behave like "blacks who enjoy eating human flesh," ${ }^{1}$ thus perpetuating anti-African racist stereotypes.

Despite her unforgiving attacks against the Christian faith, she wrote relatively little about Judaism as a religion, though most of her writings have a strong anti-Semitic subtext. She equals Judaism with Zionism and denounces it as a doctrine whose "aim is to impose the superiority of the [Jewish] race on the whole world." ${ }^{2}$ Focusing on the nameless "Jew," she reiterates anti-Semitic diatribes rooted in nineteenth century Europe. ${ }^{83}$ On the other hand, even though she rails against Zionism, she

77 Sâmiha Ayverdi, Hey Gidi Günler Hey (İstanbul: Hülbe, 1988), 26-27.

78 Ayverdi, Kaybolan Anahtar, 100.

79 Ayverdi, Misyonerlik Karşısında Türkiye, 21-22.

80 Sâmiha Ayverdi, Arkamızda Dönen Dolaplar, 56-8; Ayverdi, Yeryüzünde BirkaçAdım (İstanbul: Kubbealtı, 2008 [1984]), 26-27; Ayverdi, Kaybolan Anahtar, 95-6.

81 Ayverdi, Arkamizda Dönen Dolaplar, 147.

82 Ayverdi, Kaybolan Anahtar, 249.

83 Ayverdi's anti-Semitism was far from uncommon in Turkish religious and nationalist right-wing circles. Most probably she received inspiration from Necip Fazıl Kısakürek's journal Büyük Doğu and Cevat Rifat Atilhan's dozens of anti-Semitic publications. On the impact of those two, see Hazan Kuru, "Türkiye'de Antisemitizm ve Büyük Doğu Dergisi," (unpublished MA thesis, Yıldız Teknik Üniversitesi, İstanbul, 2010); Rifat N. Bali, "The Image of the Jew in the Rhetoric of Political Islam in Turkey," Ca- 
has very little to say about the plight of the Palestinian people, since solidarity with the Palestinians was principally a left-wing cause in Turkey before the 1980s.

Christianity and Judaism faring poorly in her worldview, it is unsurprising that she is not favorable to interreligious and intercultural dialogue. She writes that culture is a weapon used by Christians "to dilute faith in the Islamic world" in a new form of the crusades. ${ }^{84}$ Thus no dialogue is possible with what she calls "the world of Judah and the Cross," which has "prepared our destruction for years."

Ayverdi's approach to ethno-religious minorities as the agents of "Judah and the Cross" needs to be contextualized within this obsession. In her writings, she constructs an opposition between Turkish tolerance and what she presents as the treacherous behaviors of Armenians and Jews. She writes little about the Greek minority, but accuses them of being traitors as well, as their community leaders had supported the allied occupation of Ottoman Turkey after World War I and the Greek invasion of Anatolia. ${ }^{86}$

Armenians and Jews are viewed as the main enemies of Turkey. In her vision of history, Armenians had an enviable status under Ottoman rule, but were manipulated by Western powers and Russia in the nineteenth century. In Türkiyénin Ermeni Meselesi (Turkey's Armenian Problem, 1976), she argued that:

The reason for the Armenian people's biased condemnation, generation after generation, with feelings of hostility, hate, and revenge and their attempts to destroy the Turkish state and nation is because they are the victims of a political conspiracy benefiting the Russians and the English. ${ }^{87}$

In the same work, she also claimed that Armenians "were brutal by nature," that they were "an ungrateful community who fired guns at all the nations that helped them," 88 thus leaving it unclear whether Armenians were simply treacherous in essence or simply the victims of imperialist manipulation. Unsurprisingly, Armenian characters, often arsonists, exploiters, courtesans, or prostitutes, are depicted unfavorably in her lit-

hiers d'Etudes sur la Méditerranée Orientale et le Monde Turco-Iranien, 29 (1999).

84 Sâmiha Ayverdi, Küplüce'deki Köşk (İstanbul: Hülbe, 1989), 259.

85 Ayverdi, Yeryüzünde Birkaç Adım, 54.

86 Sâmiha Ayverdi, Hatıralarla Başbaşa (İstanbul: Kubbealtı, 2008 [1977]), 272; Ayverdi, Arkamızdan Dönen Dolaplar, 18 and 20.

87 Sâmiha Ayverdi, Türkiye'nin Ermeni Meselesi (İstanbul: Kubbealtı, 2007 [1976]), 5.

88 Ayverdi, Türkiye'nin Ermeni Meselesi, 9. 
erary works even though her first publisher, Garbis Fikri, the owner of Inkılap Publishers, was himself Armenian. Ayverdi was convinced of the existence of an Armenian conspiracy to destroy Turkish culture, in particular the language. She held Armenian intellectuals and "communist sympathizers" responsible for the more extreme aspects of the language reform of the $1930 \mathrm{~s} .{ }^{89}$ Regarding the question of the Armenian genocide, Ayverdi argued that, indeed, genocide was perpetrated in the eastern provinces of the late Ottoman Empire, but one against the Turks, not by them. This inversion of the historical facts reached its paroxysm in her call for the Turkish state to finance an international campaign and distribute "color brochures" documenting "the massacres committed by the Armenians." 90

Her approach towards Jews, in and outside of Turkey, is rooted in her appropriation of the anti-Semitic discourse of a Jewish conspiracy to control the world. Ayverdi's primitive anticommunism, a factor in her antiArmenian discourse, is also closely linked to her anti-Semitism. Just like in the context of her attacks against missionaries, her factual ignorance of the topic is striking. In a crash course on the history of socialism, she drew the readers' attention to the Jewish origins of Karl Marx, Friedrich Engels, Georg Herwegh, Moses Hess and a rather mysterious "Vorwärts," whom she considered to be early socialist leaders. However neither Engels nor Herwegh were Jewish. Moreover, Ayverdi mistook Vorwärts, the wellknown Berlin-based social-democratic publication, for a real person. ${ }^{91}$

According to Ayverdi, the Jewish quest for world domination led them to betray the Ottomans who had given them a safe haven after their expulsion from Spain. From the end of the eighteenth century onwards, Jews in Turkey collaborated with freemasons who had sheltered them from "anti-Zionists" like herself. ${ }^{92}$ Jews, she wrote, do not hesitate to destroy those unlike them because they believe "that the whole world was created only for them."93 The threat is immense: "Europe," she argued, "smells of Jews. So do the United States." ${ }^{4}$ But there was little hope for the United States as the Jews were "the most harmful microbe" threatening the United States from within. ${ }^{95}$ She claimed not to be surprised by the power of the Jews because "despite all his efforts and his brutality, even Hitler was not able to liberate Germany from Jewish

89 Ayverdi, Kaybolan Anahtar, 56-57.

90 Ayverdi, Arkamızda Dönen Dolaplar, 117.

91 Ayverdi, Türk-Rus Münasebetleri ve Muharebeleri (İstanbul: Kubbealtı, 2004 [1970]), 36.

92 Ayverdi, Hey Gidi Günler Hey, 47-48.

93 Ayverdi, Yeryüzünde Birkaç Adım, 137.

94 Ibid., 136.

95 Ayverdi, Mülâkatlar, 324. 
domination. ${ }^{96}$ Hence she calls for Muslim and Christian intellectuals to unite to prevent the "judaization" of the world; ${ }^{97}$ yet another contradiction in her worldview. Though dialogue with Christians is condemned in some articles, she seems to have considered a Christian-Muslim alliance against Jews appears to be legitimate, if not imperative.

While Ayverdi's discourse on Armenians was based on a very cavalier treatment of historical evidence, her virulent anti-Semitism had a pathologic dimension. In both her literary and non-fiction texts, her sudden bursts of anti-Jewish rage take the reader by surprise. In an essay about the religious meaning of the month Muharrem, the first month of the Islamic calendar, she launches a sudden and unexpected attack on Judaism, Zionism, and Freemasonry-this last as "a mask of Judaism" which damaged Islam and the Ottoman Empire ${ }^{98}$ - before continuing her original discussion. A similar digression can also be found in İbrabim Efendi Konaği, her final novel. She interrupts the plot to rant against the dönme, the descendants of the Jews who had converted to Islam alongside Shabtai Tzevi, a self-declared messiah, in the seventeenth century, referring to their religious fanaticism and biological degeneration. ${ }^{99}$

That this particular book should have been chosen in 2004 by the Turkish Ministry of Education as one of the 100 books that ought to be read by every high-school student exposes the ideological orientation of the Turkish government at the time. But what ought to be made of the stance of Western scholars who admired Ayverdi's work and have represented her as the advocate of a mystical and tolerant interpretation of Islam? Annemarie Schimmel, perhaps Ayverdi's most outspoken promoter in the West, must have read Ayverdi's condemnation of the dönme in the above-cited novel and interpreted it as a denunciation of "the harbingers of Zionism." 100 Zionism, on the other hand, is only mentioned in an anti-Semitic and anti-Masonic tirade by one of the characters. In that passage, the publishers considered it helpful to indicate in square brackets that "Zionist" was synonymous with "Judaic."101 This did not disturb Schimmel, who, in 1995, even dedicated Meine Seele ist eine Frau [My Soul is a Woman], her study of the feminine in Islam, to Ayverdi, to whom she felt she "owed so much that is precious." ${ }^{102}$ It is true that

\footnotetext{
96 Ayverdi, Yeryüzünde Birkaç Adım, 202.

97 Ibid.,136

98 Ayverdi, Kaybolan Anahtar, 249.

99 Ayverdi, Ibrahim Efendi Konağı, 134. On the Dönme community, see Marc David Baer, The Dönme: Jewish Converts, Muslim Revolutionaries, and Secular Turks (Stanford: Stanford University Press, 2009). 100 Schimmel, "Eine Istanbuler Schriftstellerin," 577.

101 Ayverdi, Ibrahim Efendi Konağı, 288-9.

102 Annemarie Schimmel, Meine Seele ist eine Frau: Das Weibliche im Islam (Munich: Kösel, 1995), 8.
} 
Ayverdi's vision of the "other," arguably the darkest side of her Weltanschauung, is not necessarily revealed by focusing uniquely on her mystical writings or by a selective reading of her fiction and non-fiction, where she also happens to praise principles of tolerance and moderation as taught by the prophet Muhammad and practiced by Ottoman rulers. Indeed, there is a huge gap between her celebration of Ottoman and Islamic tolerance and her own bigoted view of ethno-religious minorities. Ayverdi's mystical short fiction sometimes reached the same intensity as similar pieces by Khalil Gibran Khalil or Rabindranath Tagore and thus could beguile some Western scholars and readers interested in mysticism and its contemporary literary expressions. This might explain why Camille Adams Helminsky, editor of an anthology of Islamic mystical writing, refers to Ayverdi as a Sufi author who "never hesitated to ply her pen in an attempt to better the relationship of human being to human being, and human being with his or her Creator." 103

But scholars such as Annemarie Schimmel and Otto Spies, who were on friendly terms with Ayverdi and attended her salons, could not have ignored her more virulent views. Indeed, the publication of her sobbets, or causeries, shows that she was outspoken in these views during her meetings with friends and followers. It is unlikely that she would not have mentioned her political mantra during her meetings with her German friends. Just like Schimmel, Spies must have known that her engagement with tradition, of which he thought highly, ${ }^{104}$ were underpinned by a much more unavowable worldview. Perhaps the little interest shown by Spies and Schimmel in Ayverdi's ultra-reactionary stance could be explained by the shadowy secrets they guarded about their own academic careers in national-socialist Germany. ${ }^{105}$

Arguably the most striking paradox of her literary career was that while Ayverdi should have obtained literary recognition for her attempts to subvert both classical Ottoman and Western literary traditions, she

103 Camille Adams Helminski, Women of Islam: A Hidden Treasure (Boston: Shambala, 2003), 300.

104 Otto Spies, "Die neue Türkei im Spiegel der modernen türkischen Literatur," Das Parlament (24 August 1960), 559-69.

105 On the collaboration between Orientalists and the national-socialist regime, see Ekkehard Ellinger, Deutsche Orientalistik zur Zeit des Nationalsozialismus 1933-1945 (Edingen-Neckarhausen: Deux Mondes, 2006). Otto Spies most probably became a member of the National Socialist party in 1933 (36), and took advantage of purges in the German academic world. He obtained a Professorship at the University of Breslau in 1936, the chair that had been occupied by Professor Carl Brockelmann who had incurred the wrath of the Nazi authorities (41-5). Less is known about Schimmel's position in Nazi Germany. She was much younger and worked as a translator for the German Ministry of Foreign Affairs during World War II (191). She became a member of the Deutsche Morgenländische Gesellschaft in 1940 (77-86) and of the Deutsche Gesellschaft für Islamkunde in 1943, a learned society whose membership had shrunk to 79 people, after various purges (103). 
was acknowledged by some Islamologists in Europe for something she, at least during the latter part of her career, did not attempt: advocacy of an enlightened and tolerant Islam embracing plurality.

\section{Conclusion}

Sâmiha Ayverdi started out in the 1930s as a disciple of Kenan Rifầ and a novelist who preached mystical union with God with the help of a Sufi master. However, developments after the military takeover of 1960, particularly the mass conversion of the Turkish intelligentsia to socialism and the eruption of street fighting between right- and left-wing factions, weighed on her to such an extent that the predominant message of mystical love in her earlier writings gradually gave way to a harsher and darker one. Ayverdi's post-1960 career could easily be described as that of a typical Turkish right-wing intellectual of the Cold War years. The dominant leitmotifs in her post-1960 works, were anti-communism, the search for Islamic respectability, and rehabilitation of the Ottoman past. As well as her conservative literary taste, the key factors which helped spread Ayverdi's reputation as the heroine of the Turkish Right were her willingness to put her family money, prestige, and connections behind right-wing causes.

The circle of women who gathered first around Kenan Rifaî and subsequently Sâmiha Ayverdi presents us with a much more complex view of what it meant to be a Muslim activist woman in the 20th century Middle East. Although there were very few other Islamist women with comparable public visibility in that generation, Ayverdi was still not alone. There are interesting parallels, for example, between Ayverdi's career and that of Labiba Ahmad (c. 1875-1951), an Egyptian Islamist woman who was some thirty years Ayverdi's senior. Like Ayverdi, Ahmad was born into the-Cairene-middle class; she, too, was a conservative but "active" woman, a founder of charity institutions that aimed to fasten Islam and Egyptian nationalism together; Ahmad also wanted to set an example for other Muslim women and to counterbalance the influence of "new secular women" in Egypt. ${ }^{106}$ However, the parallels stop there. Even if Ayverdi and Ahmad agreed on the root causes of the maladies that afflicted the Muslim ummah, they recommended very different solutions. Whereas Ahmad aimed to lead a mass movement and even showed willingness to use radio broadcasts to reach the maximum number of devotees, ${ }^{107}$ Ayverdi was reluctant to extend membership of her

106 Baron, Egypt as a Woman, 191, 213.

107 Ibid., 207-8. 
circle beyond a limited number of select initiates, who, she hoped, would one day become elite movers and shakers in the Turkish cultural and political scene. If Ahmad was ideologically close to the Muslim Brotherhood and Hasan al-Banna, ${ }^{108}$ Ayverdi advocated her modernized, Sufi interpretation of Islam as opposed to the teachings of traditional or salafi ulema. When she had to pick a side during the atmosphere of terror in the 1970s, Ayverdi's choice would be the ultra-nationalist MHP, rather than the Islamist-and politically more powerful-MSP (Milli Selamet Partisi, National Salvation Party) of Necmettin Erbakan. Most important of all, in contrast to Ahmad's black head covering, dark robes, and veil, ${ }^{109}$ Ayverdi and other women in her circle were virtually indistinguishable from the secular, Kemalist women of their time.

The case of the Ayverdi circle also leads us to question and critically engage some of the paradigmatic - and today almost banal—clichés of modern Turkish intellectual history. The trend in the scholarship has been to focus on the early republic and to juxtapose Kemalism against its others, namely the socialists, Kurds, and, especially, right-wingers of all sorts. The hidden assumption behind this paradigm is to approach this political-cum-intellectual struggle as if it were trench warfare in which both sides had dug in and clutched on to a set of easily recognizable, internally coherent, and monolithic views. The obvious result of this tendency is to distort a complex reality to be able to fit individuals into neatly defined categories. To give a few examples from the Turkish Right, Nihâl Atsız's fight against political Islam, Mümtaz Turhan and Münevver Ayaşlı's elitism, Nurettin Topçu's socialism, Necip Fazıl Kisakürek's unconventional private life are too easily, and sometimes skillfully, ignored to provide an immaculate image untainted by the "sins" of the political-intellectual adversary. In a similar fashion, the fact that the so-called Kemalist ideology could be dissected into several Kemalisms and that it was actually an umbrella term that provided shelter to Westernist, leftist, and conservative factions of politicians and intellectuals simultaneously is often overlooked. What is missing in these accounts is sympathy for human diversity; what is abundant, on the other hand, is an eagerness to erect an impregnable defensive wall to distinguish one political-intellectual position from its opposite. Yet, these typical binary oppositions of modern Turkish history are not so unassailable. The border that separated the Kemalist from the anti-Kemalist, the westernizer from the Islamist, and the modern from the traditional

108 Ibid., 208-9.

109 Ibid., 191. 
was not a wall but a membrane which permitted over-the-border exchange of ideas in the form of a cultural osmosis. In Sâmiha Ayverdi, we find an excellent example of why we need to overcome the urge to categorize and pay as much attention to similarities as differences. What we have called the paradoxes of Ayverdi's career, such as her distinctive interpretation of Islam, relationship with her Sufi master, tendency to employ auto-fiction, and her unabashed elitism are all characteristics which defy clichés associated with the stereotype of a conservative/nationalist/Islamist intellectual in Cold War Turkey. Although stereotypes are important cultural artifacts from which to mentally construct Weberian ideal-types, Ayverdi's case reminds us once again that we should not mistake the ideal-type for the reality.

\section{References}

Abadan-Unat, Nermin. Women in the Developing World: Evidence from Turkey. Denver: University of Denver, 1986.

—. "Social Change and Turkish Women." In Women in Turkish Society, edited by Nermin Abadan Unat, Deniz Kandiyoti, and Mübeccel B. Kıray, 5-31. Leiden: Brill, 1981.

Acar, Feride. "Women and Islam in Turkey." In Women in Modern Turkish Society, edited by Şirin Tekeli, 4665. London: Zed Books, 1995.

Adak, Hülya. "Gender-in (g) Biography: Ahmet Mithat (on Fatma Aliye) or the Canonization of an Ottoman Male Writer." Querelles: Jahrbuch für Frauen und Geschlechterforschung 10 (2005): 189-204.

Afet Inan, A. The Emancipation of the Turkish Women. Amsterdam: UNESCO, 1962.

Ann, Mary Fay, ed. Auto/Biography and the Construction of Identity and Community in the Middle East. New York: Palgrave, 2002.

Arat, Necla. Kadın Sorunu. İstanbul: İstanbul Üniversitesi Edebiyat Fakültesi, 1980.

Arat, Yeşim. "Feminism and Islam: Consideration on the Journal Kadın ve Aile." In Women in Modern Turkish Society, edited by Şirin Tekeli, 66-78. London: Zed Books, 1995.

Ayvazoğlu, Beşir. Tanrıdăgı'ndan Hıra Dağı'na: Milliyetçilik ve Muhafazakarlık Üzerine Yazılar. İstanbul: Kapı, 2010.

Ayverdi, Sâmiha. Ibrahim Efendi Konağı. İstanbul: Kubbealtı, 2009.

—. Kaybolan Anahtar. İstanbul: Kubbealtı, 2009.

—. Yeryüzünde Birkaç Adım. İstanbul: Kubbealtı, 2008.

—. Hâtıralarla Başbaşa. İstanbul: Kubbealtı, 2008.

-. Son Menzil. İstanbul: Kubbealtı, 2007.

—. Türkiye'nin Ermeni Meselesi. İstanbul: Kubbealtı, 2007.

—. Arkamızda Dönen Dolaplar. İstanbul: Kubbealtı, 2007.

—. Millî Kültür Mes'eleleri ve Maârif Dâvâmız. İstanbul: Kubbealtı, 2006.

—. Misyonerlik Karşısında Türkiye. İstanbul: Kubbealtı, 2005.

-. Mülâkatlar. İstanbul: Kubbealtı, 2005.

—. Bă̆ Bozumu. İstanbul: Kubbealtı, 2005.

_. Yaşayan Ölü. İstanbul: Kubbealtı, 2005.

—. Türk-Rus Münasebetleri ve Muharebeleri. İstanbul: Kubbealtı, 2004.

—. Ah Tuna Vah Tuna. İstanbul: Kubbealtı, 2004.

—. Dost. İstanbul: Kubbealtı, 1999.

. Küplüce'deki Köşk. İstanbul: Hülbe, 1989.

. Hey Gidi Günler. İstanbul: Hülbe, 1988.

. Edebî ve Manevî Dünyası İçinde Fatih. İstanbul: İstanbul Fetih Derneği, 1953.

Ayverdi, Sâmih, Safiye Erol, Nezihe Araz, and Sofi Huri. Kenan Rifaî ve Yirminci Asrın Işığında Müslümanlık. 
İstanbul: Kubbealtı, 2003.

Baer, Marc David. The Dönme: Jewish Converts, Muslim Revolutionaries, and Secular Turks. Stanford: Stanford University Press, 2009.

Bali, Rıfat. "The Image of the Jew in the Rhetoric of Political Islam in Turkey." Cahiers d'Etudes sur la Méditerranée Orientale et le Monde Turco-Iranien 29 (1999).

Basmacı, Sema. "Aydınlar Ocağı ve Türk-İslâm Sentezi: 1980'lerden 2000'li Yıllara Devreden Milliyetçi Muhafazakar Bakıye." MA Thesis, Hacettepe University, 2009.

Baron, Beth. Egypt as a Woman: Nationalism, Gender and Politics. Berkeley, Los Angeles and London: University of California Press, 2005.

Başvekalet İstatistik Umum Müdürlüğü. Millet Mektepleri Faaliyet istatistiği, 1928-33. İstanbul: Devlet Matbaası, 1934.

Bein, Amit. Ottoman Ulema, Turkish Republic: Agents of Change and Guardians of Tradition. Stanford: Stanford University Press, 2011.

Berkes, Niyazi. The Development of Secularism in Turkey. Montreal: McGill University Press, 1964.

Binark, İsmet. Ekrem Hakkı Ayverdi Bibliyografyası. İstanbul: Kubbealtı, 1999.

Bosworth, C. E. "Rifa'iyya." Encyclopedia of Islam, $2^{\text {nd }}$ ed. (2010).

Brice, W. C. "The Population of Turkey in 1950." The Geographical Journal 120 (1954), 351.

Copeaux, Etienne. Espaces et temps de la nation turque: analyse d'une historiographie nationaliste, 1931-1993. Paris: CNRS, 1997.

Cündioğlu, Dücane. Bir Siyasî Proje Olarak Türkçe Ibadet I: Türkçe Namaz. İstanbul: Kitabevi, 1999.

Deliorman, Altan. Işıklı Hayatlar. İstanbul: Kubbealtı, 2004.

Doğramacı, Emel. Atatürk and the Turkish Women Today. Ankara: Atatürk Araştırma Merkezi, 1991.

Ekrem Hakkı Ayverdi Hatıra Kitabı. İstanbul: Fetih Cemiyeti Yayınları, 1995.

Ellinger, Ekkehard. Deutsche Orientalistik zur Zeit des Nationalsozialismus, 1933-1945. Edingen-Neckarhausen: Deux Monde, 2006.

Enderwitz, Susanne. "Autobiography and Islam." In Autobiographical Themes in Turkish Literature: Theoretical and Comparative Perspectives, edited by Olcay Akyıldız, Halim Kara, and Börte Sagaster. Würzburg: Ergon Verlag, 2007.

Ergiydiren, Özcan. Hayâli Cihan Değer: Sâmiha Ayverdi ile Hâtıralar. İstanbul: Kubbealtı, 2009.

Ertürk, Nergis. Grammatology and Literary Modernity in Turkey. New York: Oxford University Press, 2011.

Göle, Nilüfer. The Forbidden Modern: Civilization and Veiling. Ann Arbor: University of Michigan Press, 1997.

Gözaydın, İştar. Diyanet: Türkiye Cumhuriyeti'nde Dinin Tanzimi. İstanbul: İletişim, 2009.

Göze, Hicran. Mâveradan Gelen Ses. İstanbul: Kubbealtı, 2005.

Güvenç, Bozkurt, et al. Türk-Isslam Sentezi. İstanbul: Sarmal Yayınları, 1994.

Helminski, Camille Adams. Women of Islam: A Hidden Treasure. Boston: Shambala, 2003.

İnan, Afet. Tarih Boyunca Türk Kadınının Hak ve Görevleri. İstanbul: Milli Eğitim Bakanlığı, 1975.

—. Atatürk ve Türk Kadın Haklarının Kazanılması. İstanbul: Milli Eğitim Bakanlığı, 1968.

İrem, Nazım. "Turkish Conservative Modernism: Birth of a National Quest for Cultural Renewal." International Journal of Middle East Studies 34 (2002): 87-112.

Jeanelle, Jean-Louis. "Où en est la reflexion sur l'autofiction?" In Genèse et autofiction, edited by Jean-Louis Jeanelle and Catherine Viollet, 17-37. Louvain-La-Neuve: Bruylant Academia, 2007.

Kafadar, Cemal. "Mütereddit Bir Mutasavvıf: Üsküplü Asiye Hatun'un Rüya Defteri, 1641-1643." Topkapı Sarayı Yıllığı 5 (1992): 168-222.

Kandiyoti, Deniz. "Emancipated But Unliberated? Reflections on the Turkish Case." Feminist Studies 13 (1987): 317-338.

Kaner, Nazlı. Samiha Ayverdi (1905-1993) und die osmanische Gesellschaft. Würzburg: Ergon Verlag, 1998. Kaplan, Sam. The Pedagogical State: Education and the Politics of National Culture in Post-1980 Turkey. Stanford: Stanford University Press, 2006.

Kara, İsmail. Cumhuriyet Türkiye'sinde Bir Mesele Olarak İslam. İstanbul: Dergâh, 2008.

Karay, Refik Halit. Kadınlar Tekkesi. İstanbul: İnkılap, 1999.

Karpat, Kemal. "Social Themes in Contemporary Turkish Literature." The Middle East Journal 14 (1960): 29-44 and 154-168.

Kashani, Sabet, Firoozeh. "Patriotic Womanhood: The Culture of Feminism in Modern Iran, 1900-1941." British Journal of Middle East Studies 32 (2005): 29-46.

Kuru, Hazan. “Türkiye'de Antisemitizm ve Büyük Doğu Dergisi.” MA Thesis, Yıldız Technical University, 
2010.

Lejeune, Philippe. Le pacte autobiographique. Paris: Editions du Seuil, 1996.

Lewis, Bernard. "First Person Narrative in the Middle East." In Middle Eastern Lives: The Practice of Biography and Self-Narrative, edited by Martin Kramer, 20-34. New York: Syracuse University Press, 1991.

Mardin, Şerif A. "Super-Westernization in Urban Life in the Ottoman Empire in the Last Quarter of the Nineteenth Century." In Turkey: Geographic and Social Perspectives, edited by P. Benedict, E. Tümertekin and F. Mansur, 403-445. Leiden: Brill, 1974.

. "Center-Periphery Relations: A Key to Turkish Politics?" Daedalus 102 (1973): 169-190.

. "Ideology and Religion in the Turkish Revolution." International Journal of Middle East Studies 2 (1971): 197-211.

Mignon, Laurent. Çă̆daş Türk Şiirinde Aşk, Aşıklar, Mekânlar. Ankara: Hece, 2002.

Millas, Herkül. Türk Romanı ve Öteki. İstanbul: Sabancı Üniversitesi Yayınları, 2000.

Milli Eğitim Bakanlığı. Maarif Şuraları, 1939-1981, 10 vols. Ankara: Milli Eğitim Bakanlığı, n. d.

Okay, Orhan. "Takdim." In Mâbette Bir Gece, Sâmiha Ayverdi. İstanbul: Kubbealtı, 2005.

Okay, M. Orhan. "Hâtırat - Türk Edebiyatı." İslam Ansiklopedisi (1997).

Onay, Perihan. Türkiye'nin Sosyal Kalkınmasında Kadının Rolü. Ankara: İş Bankası Yayınları, n. d.

Reynolds, Dwight F. "Introduction." In Interpreting the Self: Autobiography in the Arabic Literary Tradition, edited by Dwight F. Reynolds, 1-14. Berkeley, Los Angeles, London: University of California Press, 2001.

Ringer, Monica M. "Rethinking Religion: Progress and Morality in the Early Twentieth-Century Iranian Women's Press." Comparative Studies of South Asia, Africa and the Middle East 24 (2004): 47-54.

Saktanber, Ayşe. Living Islam: Women, Religion and the Politicization of Culture in Turkey. London and New York: I.B. Tauris, 2002.

Sargut, Cemalnur. Kenan Rifaî Ille Aşka Yolculuk. İstanbul: Sufi Kitap Yayınları, 2011.

Schimmel, Annemarie. Meine Seele ist eine Frau: Das Weibliche im Islam. Munich: Kösel, 1995.

_. "Eine İstanbuler Schriftstellerin." In Der Orient in der Forschung: Festschrift für Otto Spies zum 5 April 1966, edited by Wilhelm Hoenerbach, 569-585. Wiesbaden: Harrassowitz Verlag, 1967.

Seyhan, Azade. Tales of Crossed Destinies: The Modern Turkish Novel in a Comparative Context. New York: Modern Language Association, 2007.

Sirman, Nükhet. "Feminism in Turkey: A Short History." New Perspectives on Turkey 3 (1989): 1-34.

Spies, Otto. "Die neue Türkei im Spiegel der modernen türkischen Literatur." Das Parlament (August 24, 1960): 559-569.

Taşkıran, Tezer. Cumhuriyetin 50. Yılında Türk Kadın Hakları. Ankara: Başbakanlık, 1973.

Tekeli, Şirin, ed. Women in Modern Turkish Society. London: Zed Books, 1995.

Timuroğlu, Vecihi. 12 Eylül'ün Eğitim ve Kültür Politikaları. Ankara: Başak Yayınları, 1991.

Toprak, Binnaz. "Religion and Turkish Women." In Women in Turkish Society, edited by Nermin Abadan Unat, Deniz Kandiyoti, and Mübeccel B. Kıray, 281-292. Leiden: Brill, 1981.

- Islam and Political Development in Turkey. Leiden: Brill, 1981.

Turhan, Mümtaz. Maarifimizin Ana Dâvaları ve Bazı Hal Çareleri. İstanbul: İstanbul Yayınevi, 1954.

Uyanık, Seda. "19. Yüzyıl Osmanlı Türk Romanında Gayrımüslim İmgeler." MA Thesis, Bilkent University, 2007.

Watenpaugh, Keith. "Being Middle Class and Being Arab: Sectarian Dilemmas and Middle-Class Modernity in the Arab Middle East, 1908-1936." In The Making of the Middle Class: Toward a Transnational History, edited by A. Ricardo Lopez and Barbara Weinstein. Durham: Duke University Press, 2012.

- Being Modern in the Middle East: Revolution, Nationalism, Colonialism, and the Arab Middle Class. Princeton: Princeton University Press, 2006.

Yetiş, Kazım. Samiha Ayverdi: Hayatı ve Eserleri. Ankara: Kültür Bakanlığı, 1993.

Yüksel, Aydın. Ekrem Hakkı Ayverdi. Ankara: Kültür Bakanlığı, 1993.

Yüksel, Ayşe and Zeynep Uluant. Sâmiha Ayverdi. İstanbul: Kültür Bakanlığı, 2005.

Zihnioğlu, Yaprak. Kadınsız Inkılap. İstanbul: Metis, 2003. 